Article

\title{
Serosurvey for Infectious Agents Associated with Subfertility and Abortion in Dairy Cattle in Trinidad and Tobago, West Indies
}

\author{
Michael J. Morris 1,*(1), Jamie Sookhoo ${ }^{1}$ (D), Lemar Blake ${ }^{1}$, Arianne Brown Jordan ${ }^{1}$ (D), \\ Justine John ${ }^{1}$, Sheliza Ali ${ }^{1}$, Gervaise Sarjusingh ${ }^{1}$, Janelle St. Aime ${ }^{1}$, Edward H. Amoroso ${ }^{2}$ and \\ Christopher A. L. Oura ${ }^{1}$ \\ 1 School of Veterinary Medicine, The University of the West Indies (St. Augustine), Eric Williams Medical \\ Sciences Complex, Mount Hope, Trinidad and Tobago; jvekesh@hotmail.com (J.S.); \\ lemar.blake@sta.uwi.edu (L.B.); brown.arianne@gmail.com (A.B.J.); justinejohn1991@gmail.com (J.J.); \\ priyanka.hope.ali@gmail.com (S.A.); gervaisegs@gmail.com (G.S.); cbnellz24@gmail.com (J.S.A.); \\ chris.oura@sta.uwi.edu (C.A.L.O.) \\ 2 Nestlé, Churchill Roosevelt Highway, Trinidad and Tobago; Edward.amoroso01@gmail.com \\ * Correspondence: vetondenet@hotmail.com; Tel.: +1-(868)-645-2640-9 (ext. 4233)
}

Received: 30 March 2018; Accepted: 1 May 2018; Published: 11 May 2018

\begin{abstract}
Despite frequent reports of subfertility and abortion in dairy cattle in Trinidad and Tobago (T\&T), little is known about the potential infectious and non-infectious causes. This study set out to investigate possible infectious causes of reproductive problems by measuring the seroprevalence of four of the most significant reproductive pathogens in dairy cattle worldwide: Brucella abortus (B. abortus); Neospora caninum (N. caninum), Bovine Viral Diarrhoea virus (BVDV), and Infectious Bovine Rhinotracheitis virus (IBRV). These four reproductive pathogens have been suspected to be present in dairy cattle in T\&T for some time but, previously, studies have not been carried out to confirm their presence. Bulk milk samples were collected from 92 dairy farms across Trinidad, representing a total of 1177 dairy cattle. Four dairy farms were selected for individual milk sampling to assess in-farm seroprevalence levels. Milk samples were tested for antibodies to the four pathogens by commercial ELISA kits. The overall farm seroprevalence was $62 \%$ for $N$. caninium and $23 \%$ for IBRV, and no antibodies were detected in any of the bulk milk samples for B. abortus or BVDV. Mixed infections for IBRV and N. caninum were common. Seroprevalence levels were between $8 \%$ and $65 \%$ for N. caninum and between 3\% and 53\% IBRV on the four individual farms. These results reveal the presence of IBRV and $N$. caninum for the first time on the island of Trinidad and importantly reveal no evidence for the circulation of BVDV or B. abortus in dairy cattle in Trinidad.
\end{abstract}

Keywords: Trinidad and Tobago; ELISA; Brucella abortus; Neospora caninum; Bovine Viral Diarrhoea virus (BVDV); Infectious Bovine Rhinotracheitis virus (IBRV)

\section{Introduction}

The twin island republic of Trinidad and Tobago is the southernmost nation in the Caribbean archipelago, just $11 \mathrm{~km}$ off the northeastern coast of Venezuela. Dairy farming in Trinidad, the larger island in the Republic of Trinidad and Tobago (T\&T), mainly involves small-scale $(<30$ cows) semi-intensive farms, utilising single milking machines or hand milking for the most part [1]. There are also a small number $(<10)$ of larger state-run farms which contain 50-100 milking cows, some of which utilise multiple unit milking machines. In an agricultural census carried out in 2004, it was estimated that there were approximately 10,700 cattle and 9000 water buffalo in T\&T. In recent years, however, these numbers have been estimated to have reduced to 1500 water buffalo [2] and approximately 
5-6000 cattle (unpublished data-Nestlé Trinidad and Tobago Ltd., Valsayn, Trinidad and Tobago, Extension Services, 2018).

Fertility of dairy herds has declined throughout the world in recent years [3-5] and abortion is known to be a major cause of economic loss in both dairy and beef industries worldwide. [6]. Diseases of the reproductive system, cause reductions in fertility and the magnitude of their effect depends on the severity and timing of the condition [7-9] and the herd management practices [10]. To date, no studies have been published from T\&T investigating the economic impact of reproductive losses, abortion and reduction in fertility on the dairy farming industry in the country. Problems related to sub-fertility and abortion in dairy cattle are frequently reported by farmers, but detailed investigations are seldom carried out, leading to no definitive diagnosis. A large ten-year bovine abortion study carried out in the Midwestern United States, demonstrated that approximately 30\% of abortions were attributed to an infectious cause, with half of those due to bacterial pathogens and $10 \%$ due to viral pathogens, almost equally divided between IBRV and BVDV [11]. In a UK study, BVDV, IBRV, Leptospira hardjo, and mixed bacterial/fungal infections were identified most often in cases eliciting a definitive diagnosis [12].

Diseases, such as Infectious Bovine Rhinotracheitis (IBR), Bovine Viral Diarrhoea (BVD), Neosporosis, and Brucellosis, are well known for causing infertility, sub-fertility, and abortions in dairy cattle [11]. N. caninum is an obligate intracellular parasite that has been documented as a major cause of abortion in cattle worldwide [13]. No studies have been published on the prevalence on N. caninum in cattle in T\&T and the wider Caribbean region, although three studies in Grenada revealed the presence of the parasite in sheep and goats [14] and dogs [15], but not in pigs [16]. A seroprevalence study conducted in Mexico revealed a N. caninum seroprevalence of $72 \%$ among cattle, with associated high rates of abortion [17]. Brucella abortus (B. abortus) has been previously identified to be present in T\&T cattle and buffalo [18], although seroprevalence studies have not been reported in domestic cattle and buffalo in recent years. Unconfirmed reports, however, indicate that B. abortus is circulating in some buffalo populations in Trinidad. Additionally, the current status of B. abortus circulation in domestic cattle is unknown. As B. abortus is a zoonotic pathogen, it is critically important to know whether (or not) the bacteria is currently circulating in the dairy cattle population.

There are no previous published reports of the presence of Infectious Bovine Rhinotracheitis virus (IBRV) and Bovine Viral Diarrhoea virus (BVDV) in T\&T and the wider Caribbean region. These two above-mentioned viruses are known to be circulating in the USA and Canada [19,20], countries that have been used in the past to source cattle for export into Trinidad. There is, therefore, an as yet unknown risk that these two viruses have been brought into Trinidad within imported cattle.

This study therefore set out to generate baseline data related to the circulation of four important reproductive pathogens (IBRV, BVDV, B. abortus, and N. caninum) in dairy cattle in T\&T.

\section{Materials and Methods}

\subsection{Sampling Strategy and Sample Collection}

A brochure was distributed to all of the farmers participating in the study, detailing relevant information on the aims and objectives of the project, including information of the four reproductive pathogens under study. Bulk milk sampling was opportunistic and took advantage of the fact that the majority of dairy farms in Trinidad sell their milk directly to the company Nestlé, who then process and distribute the milk mostly within T\&T and the wider Caribbean region.

In total, bulk milk samples were collected from 92 dairy farms across the length and breadth of Trinidad, representing 1177 dairy cattle (Figure 1). Two sets of bulk milk samples ( $15 \mathrm{~mL}$ each) were collected from each of the 92 farms. The bulk milk samples $(15 \mathrm{~mL})$ were collected into Universal tubes each containing a potassium dichromate preservative tablet (Lactab Mark III, Thompson and Capper Ltd., Cheshire, UK). 


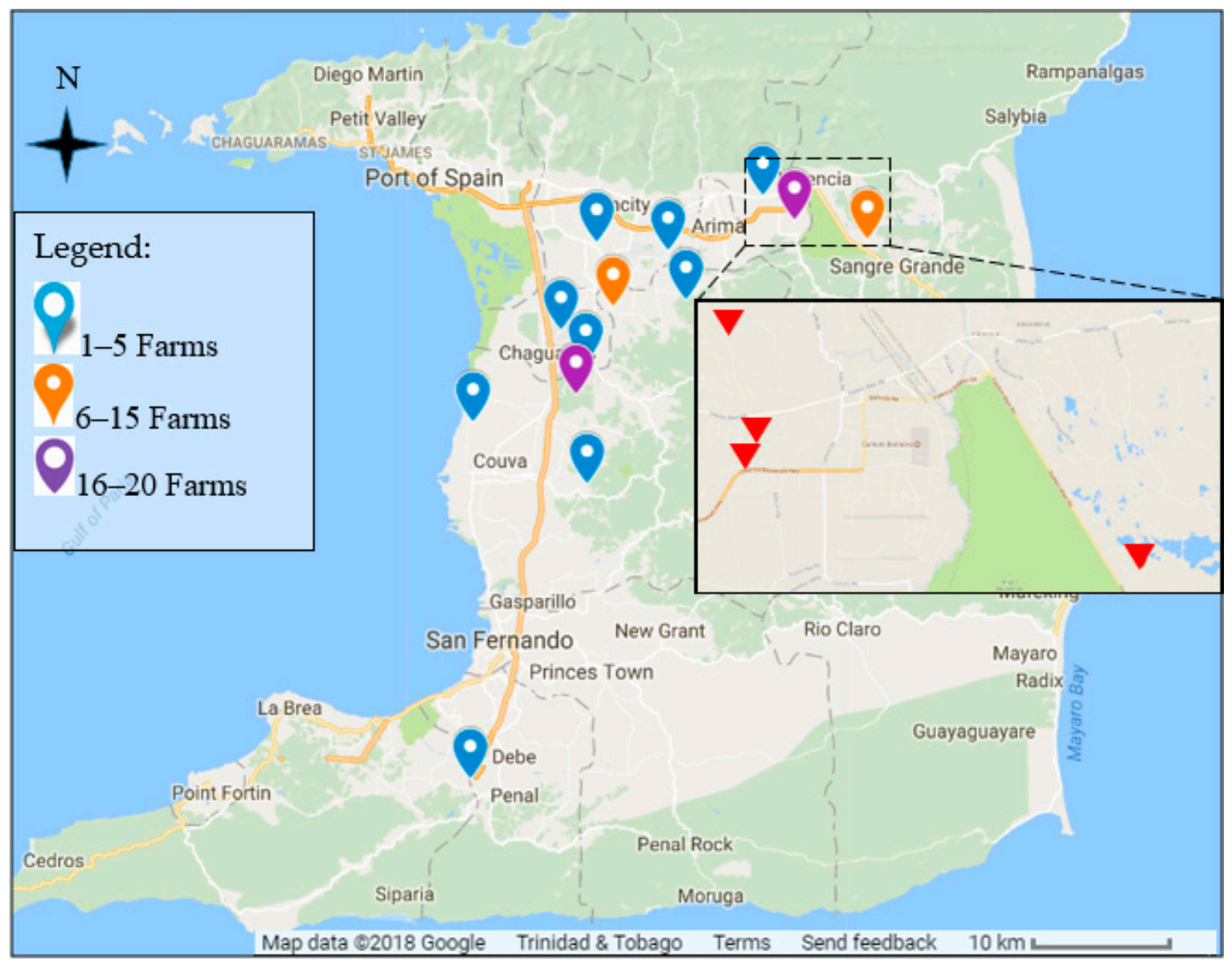

Figure 1. Map of Trinidad and Trinidad $\left(10.6918^{\circ} \mathrm{N}, 61.2225^{\circ} \mathrm{W}\right)$ showing locations of dairy farms where bulk milk samples were collected. Inset: Wallerfield-Turure area showing locations of the four farms where individual milk samples were taken.

Four farms were selected for further individual milk sampling on the basis that they were antibody-positive in the bulk milk sampling for N. caninum and IBRV, and were located in a region of the country with a high density of dairy farms and frequent reports of subfertility and abortions. Eighty-five (85) milk samples were collected from all the milking dairy cattle in the four selected farms during the afternoon milking period. After the foremilk was removed, a sample of milk $(15 \mathrm{~mL})$ was collected manually into a universal tube containing a potassium dichromate preservative tablet (Lactab Mark III, Thompson and Capper Ltd., Cheshire, UK).

\subsection{Serological Testing}

All milk samples were tested for antibodies to IBRV, BVDV, N. caninum, and B. abortus by enzyme-linked immunosorbent assay (ELISA) using commercial test kits against the various pathogens (Table 1) following the manufacturer's instructions. Specific details of the ELISA kits used, along with the sensitivities and specificities of the assays, are shown in Table 1. All ELISA tests were performed in duplicate as per the manufacturer's instructions.

In the event of all samples testing negative for a particular infectious disease, the probability of having missed a positive sample in the total population was determined as 1 minus the probability that T\&T is free of infection. Ausvet Freecalc [21] was used to estimate the probability of having missed a positive sample, taking into consideration the expected prevalence for that disease at a $95 \%$ confidence [22,23]. 
Table 1. ELISA kits used for the detection of antibodies against four bovine infectious agents.

\begin{tabular}{llccc}
\hline Infectious Agent & Test Kit & Sensitivity (\%) & Specificity (\%) & Company/Manufacturer \\
\hline $\begin{array}{l}\text { Infectious Bovine } \\
\text { Rhinotracheitis virus (IBRV) } \\
\text { Bovine Viral Diarrhoea Virus } \\
\text { (BVDV) }\end{array}$ & $\begin{array}{l}\text { LSIVet Bovine IBR Screening } \\
\text { Advanced-Milk }\end{array}$ & 100 & 100 & LSIVet $^{\mathrm{TM}}$ \\
LSIVet Ruminant BVD/BD & $97-$ Serum/Milk & 97.3 & LSIVet $^{\mathrm{TM}}$ \\
Neospora caninum & $\begin{array}{l}\text { LSIVet Bovine Neosporosis } \\
\text { Advanced-Serum/Milk }\end{array}$ & 100 & 98.5 & LSIVet $^{\mathrm{TM}}$ \\
Brucella abortus & $\begin{array}{l}\text { IDEXX Brucellosis } \\
\text { Milk—Bovine }\end{array}$ & 100 & 95 & IDEXX \\
\hline
\end{tabular}

\section{Results}

Bulk milk samples from the 92 dairy farms were tested for antibodies to B. abortus, N. caninum, BVDV, and IBRV. All bulk milk samples tested negative for antibodies to B. abortus and BVDV. One bulk milk sample from the 92 farms tested low positive for B. abortus antibodies. This farm was subsequently revisited and all the individual cattle on the farm were sampled, with all samples testing negative for B. abortus antibodies. The probability of having missed a positive sample for BVDV and B. abortus in a population of 6000 cattle at an expected prevalence of $5 \%$ for BVDV and $15 \%$ for B. abortus, calculated using Ausvet FreeCalc (2018) with a 95\% confidence, was 0.0467 and 0.05, respectively.

Nineteen (19) of the 92 dairy farms (20.7\%) tested positive for antibodies to IBRV. Sixty-five (65) of the 92 farms (70.7\%) tested positive for antibodies to N. caninum.

Individual milk samples were collected from all the milking cattle on four selected farms and were tested for antibodies to B. abortus, N. caninum, BVDV, and IBRV. All milk samples tested negative for antibodies to B. abortus and BVDV. The seroprevalence for IBRV ranged from 8-65\% and the seroprevalence for N. caninum on the four farms ranged from 3-53\% (Table 2).

Table 2. Percentage of dairy cattle positive for antibodies to IBRV and Neospora caninum.

\begin{tabular}{cccc}
\hline & Number of Cattle & IBRV_\% Positive (No.) & N. caninum-\% Positive (No.) \\
\hline Farm 1 & 17 & $65(11)$ & $53(9)$ \\
Farm 2 & 39 & $8(3)$ & $3(1)$ \\
Farm 3 & 15 & $53(8)$ & $40(6)$ \\
Farm 4 & 17 & $18(3)$ & $29(5)$ \\
\hline
\end{tabular}

\section{Discussion}

B. abortus, BVDV, IBRV, and N. caninum are responsible for causing major reproductive losses in dairy cattle worldwide $[11,23,24]$. Apart from B. abortus, which has previously been identified to be present in cattle and water buffalo in T\&T [25], there have been no reports in the literature describing the presence of these pathogens in T\&T. This study was, therefore, designed to specifically address whether any of these common reproductive pathogens were circulating in dairy cattle in T\&T, and whether they were likely to be causing reproductive losses (abortion, infertility, and subfertility) as suspected.

Brucellosis was first diagnosed in T\&T in 1998, when a Holstein-cross cow that suffered a late-term abortion was found to be serologically positive. In later investigations, B. abortus was isolated from seropositive domestic cattle and water buffalo [18]. Between 1998 and 2001, a nationwide testing program was implemented during which time many seropositive cattle and water buffalo were sent to slaughter [25]. Studies have, however, continued to identify seropositive water buffalo in Trinidad [26]. There is a high risk that $B$. abortus may pass from water buffalo to dairy cattle, as both species often share grazing pastures and are often present on the same farms. B. abortus is an important zoonotic pathogen, so it is very important to know whether it is present (or not) in the domestic cattle population [27]. In the only study on the human population in Trinidad, 394 at-risk livestock/farm and abattoir workers all tested negative for B. abortus antibodies [28]. However, unpublished data identified the presence of 
three seropositive farm workers in 1998, when B. abortus cases were first discovered in cattle in Central Trinidad. To our knowledge, B. abortus has never been identified to be present in either cattle or humans on the sister island of Tobago. The result of this study, showing no evidence for B. abortus antibodies in the 92 dairy cattle farms that were sampled, is highly significant, as it indicates that B. abortus in unlikely to be circulating in the dairy cattle population of T\&T. This important zoonotic pathogen is, therefore, currently likely to be confined to certain water buffalo populations in T\&T, making its control and possible eradication from the country a viable prospect. These results also emphasise the importance of carrying out regular surveillance of the cattle and water buffalo populations in Trinidad for B. abortus, which could be carried out relatively easily through bulk milk sampling.

This study reports the first recorded identification of cattle with antibodies to IBRV in the Caribbean, although there are several previous reports of IBR in Central and South America [29-34]. Identification of antibodies to IBRV indicates that the virus is circulating within the cattle population in $\mathrm{T} \& \mathrm{~T}$, so it is possible that this virus is causing cases of respiratory signs and reproductive problems observed in T\&T cattle, which have so far gone undiagnosed. IBRV is transmitted horizontally between cows and by extension from farm to farm [35]. Consequently, given that there are many IBRV-negative farms present in T\&T, which should work to maintain their negative status, the importance of maintaining good levels of biosecurity on farms and avoiding the movement of cattle from IBRV-infected to -free farms is of paramount importance. It has been shown that IBR spread to a previously uninfected farm can result in a $1 \mathrm{~kg}$ per cow per day decrease in milk production, resulting in decreased profitability [36]. This can be particularly devastating if the disease is introduced to the national herd [37].

The economic costs of BVDV infections worldwide vary markedly within, and between, countries [38]. In one year, BVD was estimated to cost between $\$ 760$ million- $\$ 2.2$ billion to producers in the USA [39]. For some time, farmers and vets in T\&T have suspected that BVDV was present. However, the results from this study indicate that it is not present, which is good news for T\&T, considering the seriousness and potential economic impact of the disease. BVDV has been documented to be present in dairy cattle in Uruguay, where 69\% of cattle were seropositive [33], in Brazil [40], where a seroprevalence of $52 \%$ was demonstrated in the water buffalo and in Costa Rica, where seroprevalence levels of 19\% and 27\% were identified in cattle for BVD types 1 and 2, respectively [29].

N. caninum has been documented to be present in the English-speaking Caribbean, in Grenada, but only in dogs [15,41], sheep and goats [14], and pigs [16]. Although this is the first report of the presence of N. caninum in dairy cattle in T\&T, serological evidence for the very similar Toxoplasma gondii has been reported for water buffalo [42], goats [43], and dogs [44]. With the known widespread and worldwide distribution of N. caninum, and its life cycle that includes dogs as definitive hosts, it is not surprising that the parasite is present in the cattle population of T\&T. In many cattle farms in T\&T, there is very close contact between cattle and farm dogs. The 65\% seroprevalence level observed in cattle in this study is consistent with other studies from other countries $[17,45]$. It should also be noted that vertical, rather than horizontal, transmission between cattle is considered to be a major route of transmission, in one study being estimated at $44 \%$ [46].

It is important to note that seropositivity alone does not necessarily correlate with reproductive problems in all situations [47]. Identification of the actual pathogen itself in the aborting dam and/or in the aborted foetus or placental tissues is the best way of confirming that the pathogen is responsible for the abortion. Ideally, the routine investigation of all bovine abortion cases in a country should be carried out; however, this is neither a legal requirement nor a reality in the majority of Caribbean countries, including T\&T. Even in countries with legislated bovine abortion reporting schemes, compliance is less than ideal [48]. The relatively high number of undetermined cases, $67 \%$ of nearly 9000 cases in one large study [11], possibly explains the reluctance to invest time and money into trying to gain a definitive diagnosis. The results provided in this study will hopefully be used to generate a standardized policy for the reporting of abortions in dairy cattle in T\&T. 


\section{Conclusions}

This study highlights the importance of regular serological monitoring of dairy cattle for economically important reproductive pathogens. Although antibodies to BVDV and B. abortus were not observed in T\&T dairy cattle in this study, continued monitoring for these viruses is paramount, as outbreaks are being reported in neighbouring South American countries, and B. abortus is actively circulating in water buffalo in Trinidad. The presence of IBRV in $23 \%$ of dairy cattle farms in Trinidad emphasizes the need for uninfected farms to remain free of the virus through heightened biosecurity and movement restrictions. The high farm prevalence observed for N. caninum $(62 \%)$ is not surprising, as this parasite is present in cattle in most countries around the world. Breaking the life cycle of the parasite, however, through reducing contact between dogs and cattle, especially at calving times, is strongly recommended as a control and prevention measure.

Author Contributions: All authors were involved in the design of the study. L.B. and A.B.J. also provided field and laboratory support. J.J., S.A., G.S., J.S.A., and E.H.A. also carried out the major field work. M.J.M., J.S., and C.A.L.O. have drafted and critically reviewed the manuscript for important intellectual content and have given approval for the final version to be published.

Funding: This project was supported by a grant from the University of the West Indies Campus Research and Publication Fund.

Acknowledgments: Nestlé Trinidad and Tobago Ltd. are acknowledged for partially funding the ELISA kits and for providing access to the milk processing plant from where the bulk milk samples were collected. We would like to acknowledge the dairy farmers of Trinidad who allowed us to collect and test milk samples from their cattle. The School of Veterinary Medicine (SVM), the University of the West Indies, is acknowledged for partially funding the study through their student research project fund. We would also like to acknowledge the Livestock and Livestock Products Board for supporting the study.

Conflicts of Interest: The authors declare no conflict of interest.

\section{References}

1. Romain, H.T.; Adesiyun, A.A.; Webb, L.A.; Lauckner, F.B. Study on risk factors and their association with subclinical mastitis in lactating dairy cows in Trinidad. J. Vet. Med. B Infect. Dis. Vet. Public Health 2000, 47, 257-271. [CrossRef] [PubMed]

2. Mohammed, A.; Diptee, M.; Persad, A.; Mohammed, R.; Lambie, N.; Sieuchand, S. A status report on the water buffalo (Bubalus bubalis Linnaeus, 1758) industry in Trinidad. Trop. Agric. 2017, 94. [CrossRef]

3. Royal, M.D.; Darwash, A.O.; Flint, A.P.F.; Webb, R.; Woolliams, J.A.; Lamming, G.E. Declining fertility in dairy cattle: Changes in traditional and endocrine parameters of fertility. J. Anim. Sci. 2016, 70, 487-501. [CrossRef]

4. Lucy, M.C. Reproductive loss in high-producing dairy cattle: Where will it end? J. Dairy Sci. 2001, 84, 1277-1293. [CrossRef]

5. Washburn, S.P.; Silvia, W.J.; Brown, C.H.; McDaniel, B.T.; McAllister, A.J. Trends in reproductive performance in Southeastern Holstein and Jersey DHI herds. J. Dairy Sci. 2002, 85, 244-251. [CrossRef]

6. Reichel, M.P.; Alejandra Ayanegui-Alcerreca, M.; Gondim, L.F.; Ellis, J.T. What is the global economic impact of Neospora caninum in cattle-The billion dollar question. Int. J. Parasitol. Parasites 2013, 43, 133-142. [CrossRef] [PubMed]

7. Pellerin, C.; van den Hurk, J.; Lecomte, J.; Tijssen, P. Identification of a new group of bovine viral diarrhea virus strains associated with severe outbreaks and high mortalities. Virology 1994, 203, 260-268. [CrossRef] [PubMed]

8. Grooms, D.L. Reproductive consequences of infection with bovine viral diarrhea virus. Vet. Clin. N. Am. Food Anim. Pract. 2004, 20, 5-19. [CrossRef] [PubMed]

9. Stenlund, S.; Kindahl, H.; Uggla, A.; Bjorkman, C. A long-term study of Neospora caninum infection in a Swedish dairy herd. Acta Vet. Scand. 2003, 44, 63-71. [CrossRef] [PubMed]

10. Chi, J.; VanLeeuwen, J.A.; Weersink, A.; Keefe, G.P. Management factors related to seroprevalences to bovine viral-diarrhoea virus, bovine-leukosis virus, Mycobacterium avium subspecies paratuberculosis, and Neospora caninum in dairy herds in the Canadian maritimes. Prev. Vet. Med. 2002, 55, 57-68. [CrossRef] 
11. Kirkbride, C.A. Etiologic agents detected in a 10-year study of bovine abortions and stillbirths. J. Vet. Diagn. Investig. 1992, 4, 175-180. [CrossRef] [PubMed]

12. Murray, R.D. A field investigation of causes of abortion in dairy cattle. Vet. Rec. 1990, 127, 543-547. [PubMed]

13. Dubey, J.P.; Lindsay, D.S. A review of Neospora caninum and neosporosis. Vet. Parasitol. 1996, 67, 1-59. [CrossRef]

14. Sharma, R.N.; Bush, J.; Tiwari, K.; Chikweto, A.; Bhaiyat, M.I. Seroprevalence of Neospora caninum in sheep and goats from Grenada, West Indies. Open J. Vet. Med. 2015, 5, 219-223. [CrossRef]

15. Sharma, R.; Kimmitt, T.; Tiwari, K.; Chikweto, A.; Thomas, D.; Lanza Perea, M.; Bhaiyat, M.I. Serological evidence of antibodies to Neospora caninum in stray and owned Grenadian dogs. Trop. Biomed. 2015, 32, 286-290. [PubMed]

16. Sharma, R.N.; Tiwari, K.; Chikweto, A.; DeAllie, C.; Bhaiyat, M.I. Prevalence of antibodies to Toxoplasma gondii and Neospora caninum in pigs in Grenada, West Indies. Open J. Vet. Med. 2015, 5, 138-141. [CrossRef]

17. Morales, E.; Trigo, F.J.; Ibarra, F.; Puente, E.; Santacruz, M. Seroprevalence study of bovine neosporosis in Mexico. J. Vet. Diagn. Investig. 2001, 13, 413-415.

18. Fosgate, G.T.; Adesiyun, A.A.; Hird, D.W.; Hietala, S.K.; Ryan, J. Isolation of brucella abortus biovar 1 from cattle and water buffaloes in Trinidad. Vet. Rec. 2002, 151, 272-273. [CrossRef] [PubMed]

19. Van Campen, H. Epidemiology and control of bovine viral diarrhea in the United States. Vet. Microbiol. 2010, 142, 94-98. [CrossRef] [PubMed]

20. VanLeeuwen, J.A.; Forsythe, L.; Tiwari, A.; Chartier, R. Seroprevalence of antibodies against bovine leukemia virus, bovine viral diarrhea virus, Mycobacterium avium subspecies paratuberculosis, and Neospora caninum in dairy cattle in Saskatchewan. Can. Vet. J. 2005, 46, 56-58. [PubMed]

21. The Australian Biosecurity Cooperative Research Centre for Emerging Infectious Disease. Ausvet Freecalc: Calculate Sample Size for Freedom Testing with Imperfect Tests. Available online: http:/ / epitools.ausvet. com.au/content.php?page=FreeCalc2 (accessed on 13 March 2018).

22. Cameron, A. Survey Toolbox: A Practical Manual and Software Package for Active Surveillance of Livestock Diseases in Developing Countries; ACIAR: Bruce, Australia, 1999.

23. Kirkbride, C.A. Bacterial agents detected in a 10-year study of bovine abortions and stillbirths. J. Vet. Diagn. Investig. 1993, 5, 64-68. [CrossRef] [PubMed]

24. Kirkbride, C.A. Viral agents and associated lesions detected in a 10-year study of bovine abortions and stillbirths. J. Vet. Diagn. Investig. 1992, 4, 374-379. [CrossRef] [PubMed]

25. Fosgate, G.T.; Diptee, M.D.; Ramnanan, A.; Adesiyun, A.A. Brucellosis in domestic water buffalo (Bubalus bubalis) of Trinidad and Tobago with comparative epidemiology to cattle. Trop. Anim. Health Prod. 2011, 43, 1479-1486. [CrossRef] [PubMed]

26. Adesiyun, A.A.; Fosgate, G.T.; Seebaransingh, R.; Brown, G.; Stoute, S.; Stewart-Johnson, A. Virulence of Brucella abortus isolated from cattle and water buffalo. Trop. Anim. Health Prod. 2011, 43, 13-16. [CrossRef] [PubMed]

27. Mailles, A.; Rautureau, S.; Le Horgne, J.M.; Poignet-Leroux, B.; d'Arnoux, C.; Dennetiere, G.; Faure, M.; Lavigne, J.P.; Bru, J.P.; Garin-Bastuji, B. Re-emergence of brucellosis in cattle in France and risk for human health. Euro Surveill. 2012, 17, 2-4.

28. Adesiyun, A.; Campbell, M.; Rahaman, S.; Bissessar, S.; Stewart-Johnson, A.; Dookeran, S.; Gittens-St Hilaire, M. Frequency of detection of immunoglobulins of Toxoplasma gondii, Leptospira spp., and Brucella abortus in livestock/farm and abattoir workers in Trinidad. J. Agromed. 2011, 16, 200-209. [CrossRef] [PubMed]

29. Raizman, E.A.; Pogranichniy, R.; Negron, M.; Schnur, M.; Tobar-Lopez, D.E. Seroprevalence of infectious bovine rhinotracheitis and bovine viral diarrhea virus type 1 and type 2 in non-vaccinated cattle herds in the pacific region of central Costa Rica. Trop. Anim. Health Prod. 2011, 43, 773-778. [CrossRef] [PubMed]

30. Rice, D.A.; Jenney, E.W. Serological evidence of infectious bovine rhinotracheitis, bovine virus diarrhoea and parainfluenza-3 viruses in calves in El Salvador. Trop. Anim. Health Prod. 1979, 11, 123-124. [CrossRef] [PubMed]

31. Alice, F.J. Isolation of infectious bovine rhinotracheitis virus (IBR) in Brazil (preliminary note). Rev. Bras. J. Biol. 1978, 38, 919-920.

32. Carrillo, B.J.; Ambrogi, A.; Schudel, A.A.; Vazquez, M.; Dahme, E.; Pospischil, A. Meningoencephalitis caused by IBR virus in calves in Argentina. Zent. Vet. B 1983, 30, 327-332. [CrossRef] 
33. Guarino, H.; Núñez, A.; Repiso, M.V.; Gil, A.; Dargatz, D.A. Prevalence of serum antibodies to bovine herpesvirus-1 and bovine viral diarrhea virus in beef cattle in Uruguay. Prev. Vet. Med. 2008, 85, 34-40. [CrossRef] [PubMed]

34. Campos, F.S.; Franco, A.C.; Hubner, S.O.; Oliveira, M.T.; Silva, A.D.; Esteves, P.A.; Roehe, P.M.; Rijsewijk, F.A. High prevalence of co-infections with bovine herpesvirus 1 and 5 found in cattle in southern Brazil. Vet. Microbiol. 2009, 139, 67-73. [CrossRef] [PubMed]

35. Vonk Noordegraaf, A.; Buijtels, J.A.; Dijkhuizen, A.A.; Franken, P.; Stegeman, J.A.; Verhoeff, J. An epidemiological and economic simulation model to evaluate the spread and control of infectious bovine rhinotracheitis in the Netherlands. Prev. Vet. Med. 1998, 36, 219-238. [CrossRef]

36. Van Schaik, G. Risk and economics of disease introduction to dairy farms. Tijdschr. Diergeneeskd. 2001, 126, 414-418. [PubMed]

37. Van Schaik, G.; Schukken, Y.H.; Nielen, M.; Dijkhuizen, A.A.; Barkema, H.W.; Benedictus, G. Probability of and risk factors for introduction of infectious diseases into Dutch SPF dairy farms: A cohort study. Prev. Vet. Med. 2002, 54, 279-289. [CrossRef]

38. Richter, V.; Lebl, K.; Baumgartner, W.; Obritzhauser, W.; Kasbohrer, A.; Pinior, B. A systematic worldwide review of the direct monetary losses in cattle due to bovine viral diarrhoea virus infection. Vet. J. 2017, 220, 80-87. [CrossRef] [PubMed]

39. Driskell, E.A.; Ridpath, J.F. A survey of bovine viral diarrhea virus testing in diagnostic laboratories in the United States from 2004 to 2005. J. Vet. Diagn. Investig. 2006, 18, 600-605. [CrossRef] [PubMed]

40. Thompson, J.A.; de Miranda Henriques Leite, R.; Goncalves, V.S.; Leite, R.C.; Bandeira, D.A.; Herrmann, G.P.; Moreira, E.C.; Prado, P.E.; Lobato, Z.I.; de Brito, C.P.; et al. Spatial hierarchical variances and age covariances for seroprevalence to Leptospira interrogans serovar hardjo, BHV-1 and BVDV for cattle in the state of Paraiba, Brazil. Prev. Vet. Med. 2006, 76, 290-301. [CrossRef] [PubMed]

41. Dubey, J.P.; Stone, D.; Kwok, O.C.; Sharma, R.N. Toxoplasma gondii and Neospora caninum antibodies in dogs from Grenada, West Indies. J. Parasitol. 2008, 94, 750-751. [CrossRef] [PubMed]

42. Persad, A.; Charles, R.; Adesiyun, A.A. Frequency of toxoplasmosis in water buffalo (Bubalus bubalis) in Trinidad. Vet. Med. Int. 2011, 2011, 4. [CrossRef] [PubMed]

43. Borde, G.; Lowhar, G.; Adesiyun, A.A. Toxoplasma gondii and Chlamydophila abortus in caprine abortions in Tobago: A sero-epidemiological study. J. Vet. Med. B Infect. Dis. Vet. Public Health 2006, 53, 188-193. [CrossRef] [PubMed]

44. Ali, C.N.; Harris, J.A.; Watkins, J.D.; Adesiyun, A.A. Seroepidemiology of Toxoplasma gondii in dogs in Trinidad and Tobago. Vet. Parasitol. 2003, 113, 179-187. [CrossRef]

45. Rodriguez, I.; Choromanski, L.; Rodgers, S.J.; Weinstock, D. Survey of Neospora caninum antibodies in dairy and beef cattle from five regions of the United States. Vet. Ther. 2002, 3, 396-401. [PubMed]

46. Bergeron, N.; Fecteau, G.; Paré, J.; Martineau, R.; Villeneuve, A. Vertical and horizontal transmission of neospora caninum in dairy herds in Québec. Can. Vet. J. 2000, 41, 464-467. [PubMed]

47. Asmare, K.; Sibhat, B.; Molla, W.; Ayelet, G.; Shiferaw, J.; Martin, A.D.; Skjerve, E.; Godfroid, J. The status of bovine brucellosis in Ethiopia with special emphasis on exotic and cross bred cattle in dairy and breeding farms. Acta Trop. 2013, 126, 186-192. [CrossRef] [PubMed]

48. Bronner, A.; Henaux, V.; Fortane, N.; Hendrikx, P.; Calavas, D. Why do farmers and veterinarians not report all bovine abortions, as requested by the Clinical Brucellosis Surveillance system in France? BMC Vet. Res. 2014, 10, 93. [CrossRef] [PubMed]

(C) 2018 by the authors. Licensee MDPI, Basel, Switzerland. This article is an open access article distributed under the terms and conditions of the Creative Commons Attribution (CC BY) license (http:// creativecommons.org/licenses/by/4.0/). 